\title{
THE INFLUENCE OF PARTICIPATIVE COUNSELING APPROACH ON IMPROVING BREASTFEEDING SELF-EFFICACY TO PREGNANT WOMEN IN INDONESIA
}

\author{
FAUZIA FAUZIA ${ }^{1 *}$, NI WAYAN DIAN EKAYANTHI ${ }^{1}$, AHMAD FUDHOLI ${ }^{2}$ \\ ${ }^{1}$ Bogor Midwifery Study Program, Health Polytechnic Ministry of Health Bandung, Indonesia. ${ }^{2}$ Solar Energy Research Institute, Universiti \\ Kebangsaan Malaysia, 43600 Bangi Selangor, Malaysia. Email: zakiayuwafa@yahoo.com
}

Received: 23 October 2019, Revised and Accepted: 14 November 2019

\section{ABSTRACT}

Objective: The objective of this study was to know the effect of participatory counseling on increasing breastfeeding self-efficacy (BSE) in pregnant women in Bogor city, Indonesia.

Methods: The pre-experimental design method, namely, one group pretest-posttest, with the number of study subjects was 35 third trimester pregnant women with normal reproductive age without complications in the Bogor City. Data analysis was performed by univariable and bivariable by Friedman test and Wilcoxon post hoc test and multivariable using linear regression test.

Results: Participatory counseling has an effect on increasing breastfeeding efficacy in pregnant women $(\mathrm{p}<0.001)$, while confounding variables (education, parity, own breastfeeding experience, and other's experience of breastfeeding) have no significant effect on increasing BSE in pregnant women $(\mathrm{p}>0.05)$.

Conclusion: Participatory counseling increases BSE in pregnant women.

Keywords: Participatory counseling, Exclusive breastfeeding, Breastfeeding self-efficacy.

(c) 2020 The Authors. Published by Innovare Academic Sciences Pvt Ltd. This is an open access article under the CC BY license (http://creativecommons. org/licenses/by/4. 0/) DOI: http://dx.doi.org/10.22159/ajpcr.2020.v13i1.36167

\section{INTRODUCTION}

Exclusive breast milk is breast milk that is given to babies from birth for 6 months, without adding and/or replacing with other food or drinks (except medicine, vitamins, and minerals). Breast milk contains colostrum which is rich in antibodies because it contains protein for endurance and germ killers in high amounts so that exclusive breastfeeding can reduce the risk of death in infants. The World Health Organization recommends that all babies need colostrum $\left(1^{\text {st }}\right.$ and $2^{\text {nd }}$ days of breast milk) to fight infections and receive exclusive breastfeeding for 6 months to ensure the nutritional adequacy of infants. The most frequent breastfeeding process occurred in 1-6 h after birth $(35.2 \%)$ and $<1 \mathrm{~h}$ (early breastfeeding initiation) by $34.5 \%$, while the lowest breastfeeding process began in 7-23 $\mathrm{h}$ after births in the amount of 3.7\% [1]. The low coverage of exclusive breastfeeding is influenced by various factors. Angraresti and Syauqy [2] stated that the failure of exclusive breastfeeding was caused by lack of knowledge and attitudes related to the lack of motivation of the subjects toward exclusive breastfeeding (giving early breast milk) on the excuse that breast milk did not come out, lack of support/role of the immediate family, especially husband and mother-in-law.

Fikawati et al. [3] revealed that knowledge, experience, and education were positive predisposing factors for successful breastfeeding in Indonesia. Some obstacles in breastfeeding in the community include breastfeeding behavior that is less supportive. The same thing was stated by Fahriani's et al. research [4] which stated that the factors that were proven to influence exclusive breastfeeding were maternal psychic factors (maternal confidence in the production of breast milk), family support, mother's good knowledge of exclusive breastfeeding, and breastfeeding counseling from officers.

The mother's confidence in her ability to breastfeed or giving breast milk to her baby (breastfeeding self-efficacy [BSE]) is important in breastfeeding activities because the frequent failure of breastfeeding is caused by a mother's lack of confidence about the adequacy of breast milk and low beliefs about the ability to breastfeed. BSE is influenced by various factors including the experience of breastfeeding success itself, the other's experience of breastfeeding, physiological and psychological responses (such as fatigue, stress, and anxiety), and verbal persuasion (from family, friends, lactation consultants, or health practitioners). Reinforcement or advice given by influential people is a source of strength for mothers to breastfeed their babies [5]. Someone with high self-efficacy will be more confident in their ability to make changes in behavior because it will be easier to do it, with greater intensity and more steady in responding to initial failures than people with low selfefficacy.

Health education aims to provide or improve knowledge and attitudes about health to facilitate the occurrence of healthy behavior [6]. Thus, counseling is one of the persuasive techniques that can be used to influence a person's attitude and behavior, including in breastfeeding. The method that is often used in counseling is the top-down method, with the delivery of lecture material, the instructor sees himself as an expert, not as a facilitator so that the interaction of the participants becomes less active. Counseling with this method makes the target of counseling quickly bored and less interested so the results are not optimal. Unlike the case with the bottom-up method (participatory counseling method), where the instructor acts as a facilitator by exploring the various problems that exist in the participants, as well as taking the initiative to find solutions together. The participatory method invites the target of counseling to be more active so that it can have an impact on increasing the motivation of participants in the material presented [7]. Knowledge of exclusive breastfeeding is important to know since women become pregnant, so it is expected that the motivation for breastfeeding arises early before the mother starts breastfeeding. Thus, it is necessary to design a model of counseling for pregnant women that is appropriate to their needs so that the messages can be more effective in increasing the BSE of mothers about exclusive breastfeeding. 


\section{METHODS}

The research design used was a pre-experimental design, namely, one group pretest-posttest, which was conducted in the Bogor City Health Center Area from June to September 2018 (the Puskesmas Gang Kelor and Sindang Barang, Tanah Sareal, and Tegal Gundil areas). The study population was all normal trimester III pregnant women, with 35 subjects fulfilling the inclusion criteria: normal trimester III pregnancy, reproductive age (20-35 years), without complications of pregnancy. Calculation of the number of samples uses a large sample formula research hypothesis testing an average difference of two groups of pairs. The sampling technique was consecutive sampling. Data collection uses instruments for pre- and post-intervention activities. Before the intervention, a pre-test instrument was given to determine the initial condition of BSE. Furthermore, participatory counseling was given two meetings and then BSE measurements were made using a post-test instrument. Post-test is done 2 times, after the first and second meetings. Before the analysis, the normality of data was tested with the Shapiro-Wilk test for small samples $(\leq 50)$ with the results of self-efficacy data before counseling (pre-test) and after intervention I (post-test 1 ) were normally distributed ( $p>0.05$ ), while the data intervention II (post-test 2 ) is not normally distributed $(p<0.05)$, so the test used is non-parametric test. Non-parametric tests used are the Friedman test and the post hoc Wilcoxon test. Multivariable analysis used is linear regression.

\section{RESULTS AND DISCUSSION}

Table 1 presents the characteristics of the research subjects. Based on the above table, it is known that most of the research subjects have higher education, namely, 21 people $(60 \%)$, multigravida parity of 22 people $(62.9 \%)$, most of them, 19 people, have experienced breastfeeding themselves (54.3\%), and breastfeeding experience of others as many as 25 people $(71.4 \%)$. Table 2 presents BSE research subjects before and after participatory counseling.

Table 2 shows an increase in median self-confidence before counseling (54), after counseling/intervention I (60), and after counseling/intervention II (63). Based on the Friedman test, $p=0.000$ was obtained, then concluded at least there is an increase in BSE in pregnant women after participatory counseling. Furthermore, based on post hoc Wilcoxon, it is known that there is an increase in the confidence of pregnant women after counseling/intervention I, there is an increase in self-confidence after counseling/intervention II, and there is an increase from intervention I to intervention II with $\mathrm{p}=0.000$

\section{Table 1: Characteristics of research subjects}

\begin{tabular}{lll}
\hline Characteristic & $\mathbf{n = 3 5}$ & $\mathbf{\%}$ \\
\hline Education & & \\
$\quad$ Basic education (elementary and junior high) & 14 & 40 \\
$\quad$ Higher education (SMU and PT) & 21 & 60 \\
Parity & 13 & 37.1 \\
$\quad$ Primigravida & 22 & 62.9 \\
$\quad$ Multigravida & & \\
Self-breastfeeding experience & 19 & 54,3 \\
$\quad$ Ever & 16 & 45,7 \\
$\quad$ Never & 28 & 80 \\
Other's breastfeeding experience & 7 & 20 \\
$\quad$ Ever & & \\
$\quad$ Never &
\end{tabular}

each. Thus, Ho is rejected, meaning that there is an increase in BSE in pregnant women after participatory counseling. Table 3 presents the effect of confounding variables on increasing BSE.

\section{The effect of participatory counseling on increasing BSE in pregnant women}

From the results of the study note that the implementation of participatory counseling has a significant effect on increasing BSE in pregnant women. The mother's self-confidence in her ability to breastfeed or giving breast milk to her baby (BSE) is important in breastfeeding activities because the frequent failure of breastfeeding is caused by a lack of confidence about the adequacy of breast milk and low beliefs about the ability to breastfeed. Strengthening or advice given by influential people is a source of strength for mothers to breastfeed their babies [5]. Someone with high self-efficacy will be more confident in their ability to make changes in behavior because it will be easier to do it, with great intensity and is more stable in responding to initial failures than people with low self-efficacy. Self-efficacy is expectations and beliefs about how far a person is able to do a behavior in a certain situation. Self-efficacy determines whether we will show behavior, how strong we can survive in the face of difficulties or failures, and how success or failure in one particular task affects our behavior in the future.

Self-efficacy for mothers to give breast milk has a very big role. The first role is to determine the choice of behavior. Mothers tend to give breast milk when they feel that they have a good ability, if the mother has great confidence to give breast milk to her baby, then she will prefer giving breast milk to giving formula milk to the baby. The second role is self-efficacy as a determinant of the amount of effort and endurance in overcoming obstacles and favorable situations for breastfeeding. Mothers high self-efficacy to provide breast milk will reduce anxiety that prevents mothers from breastfeeding, thus affecting the mother's endurance to continue breastfeeding. Mothers who have high selfefficacy for breastfeeding tend to show more effort than mothers who have low self-efficacy. The third role is influencing mindset and emotional reactions. The self-efficacy affects the mindset and emotional reactions of individuals, both in dealing with current and future situations [5]. Mothers who have low self-efficacy for breastfeeding always assume that they are less able to handle the current situation or in anticipating future situations. The next role is to predict future behavior. Mothers who have high self-efficacy to breastfeed their babies have a high interest and involvement and are better with their environment. Mothers are not easily discouraged and give up in overcoming difficulties and they will display a harder effort [5]. One of the ways to improve self-efficacy in mothers is through counseling activities. Health counseling aims to provide or enhance knowledge and attitudes about health to facilitate the occurrence of healthy behavior [6]. Thus, counseling is one of the persuasive techniques that can be used to influence a person's attitudes and behavior, including maternal self-confidence in breastfeeding.

Participatory counseling is a bottom-up approach to give participants the freedom to be independent in their roles, expertise, and resources to assess their abilities so that potentials are identified, which can be actualized, including the problems found [7]. This is what distinguishes it from counseling that is usually done (top-down). The method that is often used in counseling is the top-down method, with the delivery of lecture material, the instructor sees himself as an expert, not as a facilitator so that the interaction of the counseling participants becomes less active. Counseling with this method makes the target of counseling

Table 2: Breastfeeding self-efficacy research subjects before and after participatory counseling

\begin{tabular}{llllll}
\hline Self-efficacy (breastfeeding) & $\mathbf{n}$ & Median (minimum-maximum) & Average \pm SB & IK 95\% & p* \\
\hline Confidence before counseling & 35 & $54(39-67)$ & $53.66 \pm 7.49$ & $51.08-56.23$ & $<0.001$ \\
Confidence after counseling I & 35 & $60(45-70)$ & $60.71 \pm 6.94$ & $58.33-63.10$ & $60.58-64.85$ \\
Confidence after counseling II & 35 & $63(51-70)$ & $62.71 \pm 6.22$ & \\
\hline
\end{tabular}

*Based on the Friedman test and the Wilcoxon post hoc test 
Table 3: Effect of confounding variables on increasing breastfeeding self-efficacy

\begin{tabular}{|c|c|c|c|}
\hline Variable $(n=35)$ & Amount (n) & $\%$ & $\mathbf{p}^{*}$ \\
\hline \multicolumn{4}{|l|}{ Education } \\
\hline Basic education (elementary and junior high) & 14 & 40 & 0.2 \\
\hline Higher education (SMU, PT) & 21 & 60 & \\
\hline \multicolumn{4}{|l|}{ Parity } \\
\hline Primigravida & 13 & 37.1 & 0.87 \\
\hline Multigravida & 22 & 62.9 & \\
\hline \multicolumn{4}{|l|}{ Self-breastfeeding experience } \\
\hline Never & 16 & 45.7 & \\
\hline \multicolumn{4}{|l|}{ Other's breastfeeding experience } \\
\hline Ever & 28 & 80 & 0.23 \\
\hline Never & 7 & 20 & \\
\hline
\end{tabular}

quickly bored and less interested so the results are not optimal and the material is less understood. Unlike the case with the bottom-up method (participatory counseling method), where the instructor acts as a facilitator by exploring the various problems that exist in the participants, as well as taking the initiative to find solutions together. The participatory method invites the target of counseling to be more active so that it can have an impact on increasing the motivation of participants for the material presented. In participatory counseling, the community participates interactively, analyzes are made together which ultimately leads to an action plan. Participation here uses a systematic and structured learning process involving multidisciplinary methods. This can have an impact on increasing participants' motivation toward the material presented. Research by Aseptianova and Zalili [8] concluded that there was a significant increase in the cognitive, affective, and behavior of the population toward mosquito larvae after the development of a participatory extension model. Likewise, self-confidence about breastfeeding and breastfeeding is increased after getting participatory counseling.

Participatory counseling in this study uses the method of lecture discussion, question and answer, brainstorming, simulation of breastfeeding techniques, and snake-ladder games, accompanied by cases and discussions related to breastfeeding material. With game and case media, pregnant women can learn while playing with other pregnant women so that no boredom arises, more enthusiasm for learning and material is easier to understand, understanding about breastfeeding is better. Research conducted by Ukurta et al. [9] proves that the snake-ladder game model and leaflets are effective in increasing knowledge of maternal health at reproductive age. This means that it is important to increase mother's knowledge in creative ways that can be easily understood by mothers such as through participatory counseling using game media. A mother in a household has various roles such as caregiver, worker, educator for her children, housekeeper, serving her husband, and part of the community. With many roles, the time she has to receive information is limited so that the use of media that makes it easy for mothers to understand something is very important, including an understanding of breast milk. Research conducted by Ambarwati et al. [10] shows that giving intensive lactation counseling can increase the number of mothers' who exclusively breastfeed. They also reported that prenatal counseling has an impact on breastfeeding for up to 4-6 weeks, while counseling given during prenatal and postnatal influences on exclusive breastfeeding for 6 months. Thus, breastfeeding motivation is important to be carried out continuously.

Research conducted by Wattimena and Hapsari [11] states that counseling interventions and reading about breastfeeding play a positive role in improving the attitudes and insights into mothers about breastfeeding. The same thing was found in Merdhika et al. research [12] that there were differences in the knowledge and attitudes of mothers about exclusive breastfeeding between mothers given counseling with the pocketbook method, mothers given counseling with the simulation method, and mothers given counseling without any method. Mothers who were given counseling by the pocketbook method and simulation methods had higher knowledge and attitudes compared to mothers who were given counseling without any method. Research conducted by Merdhika et al. [12] provides counseling treatment once, with the result that groups of mothers who are given counseling treatment with the pocketbook method or simulation methods have better knowledge and attitudes than groups who are not treated with any method. In addition, there is a study conducted by Putri et al. [13] about differences in memory retention after family planning (KB) counseling. From the results of the study note that memory retention after KB counseling with lecture media is lower than memory retention after $\mathrm{KB}$ counseling with video media. Thus, the importance of using appropriate media in conducting counseling and active participation of research subjects in the use of media and games can increase maternal confidence, especially in breastfeeding.

The results of the research by Komalasari et al. [14] state that the low confidence and commitment of mothers in breastfeeding and the low endurance of mothers in overcoming obstacles to breastfeeding can prevent exclusive breastfeeding. Therefore, health workers have a very important role in providing psychoeducation about breastfeeding to increase breastfeeding mothers' self-confidence. Similar to research conducted by Babakazo et al. [15] proves that a mother's confidence in her ability to breastfeed and her intention to breastfeed exclusively is the most important predisposing factor in the sustainability of exclusive breastfeeding. Confidence in the ability to breastfeed and the continuity of breastfeeding is the most important thing in preventing the failure of exclusive breastfeeding.

\section{The effect of confounding variables on increasing BSE in pregnant women}

Based on the results of the study note that confounding variables consisting of education, parity, breastfeeding experience itself, and experience of breastfeeding other people do not affect BSE in pregnant women. Thus, there is a pure influence of the independent variable (participatory counseling) with the dependent variable (increasing BSE). The research of Babakazo et al. [15] also found that there was no relationship between exclusive breastfeeding for 6 months and the sociodemographic characteristics of the mother (age, education level, marital status, family income, occupation, and parity).

Based on the characteristics, it is known that half the research subjects have primary education levels (elementary and junior high). The level of education has no effect on increasing BSE in pregnant women. This might be due to the availability of information about breastfeeding. People with higher education do not necessarily know breastfeeding correctly if they have never received information about breastfeeding, whereas people with low education do not necessarily have low beliefs about breastfeeding if they often get or are exposed to breastfeeding. Apart from health workers, information about breast milk can be obtained from print media or electronic media, so information about breast milk should be obtained more easily. The parity factor also has no 
effect on self-confidence in breastfeeding. Multiparous mothers, if they have never obtained adequate information about breast milk, will have low confidence about breastfeeding. Likewise, primiparous mothers, even though they have given birth only once, if mothers obtain adequate information about breast milk, then mothers can have high confidence about breastfeeding. In addition, a mother, either primiparous or multiparous, who does not get good support in breastfeeding, is likely to have low confidence in breastfeeding (giving breast milk).

The experience of breastfeeding both one's own experience and the experience of others also does not affect the increase in maternal self-confidence in breastfeeding. The experience may not necessarily increase the mother's confidence if the experience is a negative experience, an unpleasant event in breastfeeding, for example, experiencing breastfeeding problems or trauma (swollen breasts, abrasions or breast infections, etc.). There are other factors that may be influential that further research needs to be done, such as the influence of the husband or close family in the mother's motivation for breastfeeding. A mother who has a husband or family who does not support breastfeeding may have low confidence about breastfeeding. Limitations in this study are the experiences of both other people experiences and their own experiences of breastfeeding are not examined in depth, how the experiences faced (whether the experience is good or not good), how long to breastfeed, and so on. The use of time is less certain, such as research time which varies from one subject to another. In this study, the time ranged from 90 to $120 \mathrm{~min}$. Time measurement needs to be done for each subject to be more valid because each research subject needs different time to understand the material about breast milk and breastfeeding so that it will foster breastfeeding confidence. In addition, discussions or other questions that are less relevant to research need to be done outside the time of research to avoid bias/errors of research results. Another limitation concerns the way to measure. To correctly measure exclusive breastfeeding requires a more accurate measurement method, for example, researchers use a different research design, where mothers are given counseling about breastfeeding and breastfeeding since pregnancy, continued counseling after delivery, then followed/evaluated until breastfeeding for 6 months.

\section{CONCLUSION AND RECOMMENDATION}

From this study can conclude, (i) there is an increase in BSE after participatory counseling is given, (ii) participatory counseling increases BSE in pregnant women, and (iii) confounding variables have no effect on BSE.

The health department is expected to improve the implementation of participatory counseling and provide simple and easy to understand media related to breastfeeding to support exclusive breastfeeding efforts. Health workers, especially midwives in practice, can provide participatory counseling and motivation about breastfeeding and breastfeeding in a sustainable manner using simple and easy to understand media so that counseling can be done more effectively in the hope that it can increase the trust and confidence of mothers in breastfeeding their babies. For all pregnant women to always look for information about breast milk and breastfeeding so that breastfeeding confidence is maintained so that later it can provide breast milk exclusively to infants. Researchers can then conduct research on participatory counseling continued to postpartum and examine other factors such as husband or family support and experience studied in greater depth.

\section{ACKNOWLEDGMENT}

The authors would like to thank the Bogor City Health Office, especially the locations where data were collected, namely, the Kelor Gang Health Center, Sindang Barang, Tanah Sareal, and Tegal Gundil, Bogor City, which provided the opportunity for the authors to conduct research in this area. Acknowledgments were also expressed to the Poltekkes of the Ministry of Health in Bandung, which has funded the implementation of this research and the Bogor Midwifery Study Program for allowing the implementation of research activities.

\section{AUTHORS' CONTRIBUTIONS}

All authors contributed equally to the writing of this paper. All authors read and approved the final version of the manuscript.

\section{CONFLICTS OF INTEREST}

The authors declare that there are no conflicts of interest regarding the publication of this paper.

\section{REFERENCES}

1. Kementerian Kesehatan Republik Indonesia. Pedoman Umum Program Indonesia Sehat Dengan Pendekatan Keluarga. Jakarta: Kementerian Kesehatan Republik Indonesia; 2015.

2. Angraresti EI, Syauqy A. Faktor-faktor yang berhubungan dengan kegagalan pemberian asi eksklusif di kabupaten semarang. J Nutr Coll 2016;5:321-7.

3. Fikawati S, Syafiq A, dan Karima K. Gizi Ibu Dan Bayi. Jakarta: Raja Grafindo Persada PT; 2015.

4. Fahriani R, Rohsiswatmo R, Hendarto A. Faktor yang memengaruhi pemberian ASI eksklusif pada bayi cukup bulan yang dilakukan Inisiasi Menyusu Dini (IMD). Sari Pediatri 2014;15:394-402.

5. Spaulding DM. Breastfeeding Self Efficacy in Women of African Descent. USA: University of Massachusetts Lowel; 2007.

6. Notoatmodjo S. Promosi Kesehatan dan Ilmu Perilaku. Jakarta: Rineka Cipta; 2007.

7. Suwandi S. Penyuluhan Partisipatif. Bogor: Cekza Blog; 2006.

8. Aseptianova A, Zalili M. Pengembangan Model Penyuluhan Partisipatif dalam Pengendalian Jentik Nyamuk Penyebab Demam Berdarah (DBD) di Palembang. Hasil Seminar Nasional XII Pendidikan Biologi FKIP UNS; 2015.

9. Ukurta S, Kusumayati A, Syarifah. Intervention Model using a Game to Improve Knowledge and Attitudes of Mothers in Reproductive Age on Reproductive Health in Pernantin Village of Juhar, Karo District, Indonesia. The $2^{\text {nd }}$ International Meeting of Public Health, 2016. Indonesia: KnE Life Sciences; 2016. p. 100-8.

10. Ambarwati R, Muis SF, Susantini P. Pengaruh konseling laktasi intensif terhadap pemberian Air Susu Ibu (ASI) eksklusif sampai 3 bulan. J Gizi Indone 2013;2:15-23.

11. Wattimena I, Hapsari EW. Promosi kesehatan: Efektivitas intervensi penyuluhan dan bacaan pada ibu menyusui. J Ners Lentera 2014;2:19-26.

12. Merdhika WA, Mardji, Mazarina D. Pengaruh penyuluhan ASI eksklusif terhadap pengetahuan Ibu tentang ASI eksklusif dan sikap ibu menyusui di kecamatan Kanigoro, kabupaten Blitar. Teknol Kejuruan 2014;37:65-72.

13. Putri DM, Wahyudi F, Margawati A. Perbedaan retensi memori pasca penyuluhan keluarga berencana dengan media ceramah dan video pada wanita usia subur. J Kedokt Diponegoro 2016;5:682-93.

14. Komalasari M, Solehati T, Widianti E. Gambaran tingkat self efficacy ibu post seksio sesarea saat menyusui di RSKIA Kota Bandung. J Pendidikan Keperawatan Indones 2016;2:95-103.

15. Babakazo P, Donnen P, Akilimali P, Ali NM, Okitolonda E. Predictors of discontinuing exclusive breastfeeding before six months among mothers in Kinshasa: A prospective study. Int Breastfeed J 2015;10:19. 